\title{
Protokol Evaluasi Infeksi Jamur dan Parasit Pre dan Pasca-Transplantasi Hati Anak
}

Mulya Rahma Karyanti, Nina Dwi Putri, Hanifah Oswari

Departemen Ilmu Kesehatan Anak Fakultas Kedokteran Universitas Indonesia, Jakarta

Infeksi jamur menjadi penyebab morbiditas dan mortalitas paling penting pada pasien pasca-transplantasi hati yang mendapat beberapa imunosupresan. Candida species dan Aspergillus species adalah infeksi jamur paling invasif. Infeksi Candida species dilaporkan menjadi etiologi penyebab infeksi jamur tertinggi pada transplantasi hati. Selain infeksi jamur, parasit juga dilaporkan menjadi penyebab infeksi pada transplantasi hati khususnya pada pasien berasal dari daerah endemis. Artikel ini bertujuan untuk membuat protokol evaluasi infeksi jamur dan parasit pada transplantasi hati anak. Sari Pediatri 2020;21(6):394-400

Kata kunci: transplantasi hati, infeksi jamur, parasit, kandida, aspergillus

\section{Protocol Evaluation for Fungus and Parasitic Infection in Pre and Post Liver Transplantation in Children}

Mulya Rahma Karyanti, Nina Dwi Putri, Hanifah Oswari

Fungal infections have become a significant cause of morbidity and mortality in post-liver transplant patients receiving immunosuppressant. Candida species and Aspergillus species are the most invasive fungal infections. Candida species were reported to be the most common cause of fungal infection post-liver transplantation. Besides fungal infections, parasite was also reported being the other cause of infection in liver transplant patients, especially patients living in endemic areas. This article aims to create an evaluation protocol for fungal and parasitic infection in children post-liver transplantation. Sari Pediatri 2020;21(6):394-400

Keywords: liver transplantation, fungal infection, parasite, candida, aspergillus

Alamat korespondensi: Mulya Rahma Karyanti. Departemen Ilmu Kesehatan Anak RSUPN Cipto Mangukusumo, Fakultas Kedokteran Universitas Indonesia Jl. Diponegoro No.71 Salemba, Jakarta Pusat. Email: karyanti@ikafkui.net 
Mulya Rahma Karyanti dkk: Protokol evaluasi infeksi jamur dan parasit pre dan pasca-transplantasi hati anak

\section{Latar belakang}

Transplantasi hati merupakan pilihan efektif untuk memperpanjang kelangsungan hidup pada pasien dengan penyakit gagal hati terminal meskipun transplantasi hati dapat diikuti komplikasi infeksi yang serius. Penyebab kematian paling sering pada pasien pasca-transplantasi hati ialah infeksi jamur invasif yang disebabkan oleh kondisi imunosupresi atau diagnosis infeksi jamur yang terlambat karena gejalanya asimtomatis dan hasil pemeriksaan laboratorium yang kurang spesifik. ${ }^{1}$

Infeksi jamur pada transplantasi hati $62-91 \%$ disebabkan oleh Candida species dengan angka kematian 11-81\%. ${ }^{2}$ Berdasarkan penelitian kasus infeksi jamur pada anak di Rumah Sakit Cipto Mangunkusumo (RSCM) tahun 2012-2017, prevalensi kandidemia ditemukan sebesar 0,32\% sedangkan prevalensi aspergilosis sebesar 0,1\%. Dari 97 kasus infeksi jamur invasif pada anak yang ditemukan dalam periode 2012-2017, kandida merupakan jenis jamur penyebab terbanyak dengan jumlah sebanyak 68 kasus $(70 \%)$, diikuti aspergillus sebanyak 21 kasus (22\%). Candida albicans merupakan penyebab terbanyak kandidemia invasif sebanyak 50 kasus (51\%), sementara Candida tropicalis adalah jenis jamur terbanyak di antara kandida non-albicans (NAC) sebanyak 16 kasus (16\%) diikuti oleh Candida parapsilosis sebanyak 15 kasus $(15 \%){ }^{3}$ Walaupun infeksi parasit lebih jarang ditemukan daripada infeksi bakteri dan virus, infeksi parasit dapat meningkatkan morbiditas pada pasien pasca-transplantasi organ secara signifikan. ${ }^{4}$

Oleh sebab itu, diperlukan protokol evaluasi uji tapis infeksi jamur/parasit untuk pemberian profilaksis dan tata laksana jamur dan parasit pada pasien transplantasi hati yang dibuat berdasarkan klasifikasi level of evidence yang dikeluarkan oleh Oxford Centre for Evidence-based Medicine yang dimodifikasi untuk keperluan praktis. Peringkat bukti yang digunakan adalah (1) level I, yaitu meta analisis atau randomize clinical trial (RCT) double blind (uji klinis acak tersamar ganda); (2) level II, yaitu RCT non-double blind (uji klinis acak tidak tersamar ganda terandomisasi / nonrandomisasi); (3) level III yaitu studi observasional (kohort, potong lintang, kasus kontrol); (4) level IV yaitu konsensus dan pendapat ahli.

Derajat rekomendasi berdasarkan peringkat bukti, dapat dibuat rekomendasi sebagai berikut, Rekomendasi A bila berdasar pada bukti level I, rekomendasi B bila berdasar pada bukti level II, rekomendasi C bila berdasar pada bukti level III, rekomendasi D bila berdasar pada bukti level IV.

\section{Infeksi jamur}

\section{Etiologi infeksi jamur dan dampaknya}

Jamur merupakan organisme uniselular atau multiselular. Jamur dapat menjadi patogen yang menyebabkan infeksi pada orang yang sehat (true pathogens), seperti histoplasmosis dan coccidiomycosis atau menjadi patogen opportunistik, yaitu kandidiasis, aspergilosis dan cryptococcosis yang menyebabkan infeksi pada pasien dengan imunokompromais, seperti pasien kanker, resipien transplantasi organ, dan pasien dengan AIDS. ${ }^{5}$

Candida species merupakan etiologi infeksi jamur yang paling sering ditemukan. Infeksi biasanya muncul 0-30 hari setelah tranplantasi. Dari 41 pasien anak pasca-transplantasi hati di RSCM, ditemukan infeksi jamur berupa Candida tropicalis sebanyak 3 kasus $(7,3 \%)$ dan Candida albicans sebanyak 2 kasus $(4,8 \%){ }^{6}$ Faktor risiko infeksi jamur meliputi penggunaan terapi antibiotik dalam jangka waktu lama, penggunaan antibiotik spektrum luas, pemasangan kateter vena sentral, mendapat dialisis dan retransplantasi. ${ }^{7}$ Kateterisasi vena sentral, total nutrisi parenteral, neutropenia, dan pemakaian antibiotik selama lebih dari 14 hari ditemukan sebagai faktor risiko untuk terjadinya kandidemia pada anak. ${ }^{3}$ Aspergillus sp. juga menyebabkan $1-8 \%$ insiden infeksi pada pasien transplantasi hati. ${ }^{2}$

Pneumocystis jiroveci merupakan penyebab patogen yang dapat menyebabkan Pneumocystis Pneumonia (PCP) pada pasien pasca-tranplantasi hati. ${ }^{8}$ Penelitian yang dilakukan di Jepang pada tahun 2011 menunjukkan bahwa 19 dari 156 pasien (12,2\%) mengalami infeksi jamur sistemik, 13 kasus disebabkan oleh Candida sp., 4 kasus disebabkan oleh Pneumocystiis jiroveci, dan 2 kasus disebabkan oleh Aspergillus sp. ${ }^{9}$

\section{Uji tapis pada infeksi jamur}

Uji tapis untuk infeksi kandida sangat berguna untuk kandidat transplantasi hati. Namun, kultur darah dengan tujuan identifikasi jamur membutuhkan waktu yang lama untuk memperoleh hasil. Uji tapis infeksi jamur kandida invasif dapat dilakukan dengan 
pemeriksaan kadar 1-3 $\beta$-D-glucan (BDG) dengan sensitivitas dan spesifisitas sebesar $70 \%$ dan $87 \%$. Akan tetapi, pemeriksaan ini belum tersedia di RSCM dan pemeriksaan dengan PCR masih dikembangkan. Isolasi kandida untuk mengetahui spesies jamur penting untuk memilih antijamur yang sesuai dengan penyebab infeksi. ${ }^{10}$

Infeksi fungal sistemik aktif pada donor merupakan kontraindikasi transplantasi. Mikosis endemik khususnya muncul dalam bentuk dorman. Transmisi histoplasmosis melalui transplantasi telah dilaporkan, tetapi kebanyakan kasus tampaknya sebagai hasil dari reaktivasi infeksi terdahulu pada resipien. Uji tapis untuk deteksi aspergilosis dapat dilakukan dengan pemeriksaan antigen galactomannan di Laboratorium Parasitologi Fakultas Kedokteran Universitas Indonesia (FKUI). Sampai saat ini, rekomendasi yang seragam untuk uji tapis donor mikosis endemik belum ada. ${ }^{6}$

Uji tapis Pneumocystis jirovecii dengan pemeriksaan sputum (II-2) yang dilakukan pewarnaan menggunakan antibodi PCP (immunofluorescent, immunoperoxidase, dan sejenisnya) atau dengan pewarnaan rutin menggunakan giemsa, silver, dan sebagainya (II-1). Diagnosis menggunakan PCR pada sekret dari saluran respirasi dapat dipertimbangkan (III). Pemeriksaan sampel rutin patogen lainnya juga perlu dilakukan untuk mengetahui infeksi penyerta. Selain itu juga dapat dilakukan bronkoskopi dengan bronchoalveolar lavage untuk mendapatkan sampel diagnostik (II-2). ${ }^{11}$

\section{Profilaksis / Antijamur sebelum transplantasi hati}

Profilaksis infeksi kandida diberikan selama prosedur pre-operasi transplan hati. Nystatin diberikan dengan dosis $3 \mathrm{ml}$ jika $<20 \mathrm{~kg}$ dan $5 \mathrm{ml} \mathrm{jika} \geq 20 \mathrm{~kg}$ (kumur dan telan) 4 kali sehari selama pasien mendapat terapi steroid. ${ }^{12}$

Antijamur profilaksis sebelum transplantasi hati diberikan pada pasien risiko tinggi pasca-operasi. Antijamur lainnya yang dapat diberikan adalah Mycafungin $1 \mathrm{mg} / \mathrm{kg} /$ hari 1 kali secara intravena diberikan selama 21 hari atau sampai pasien pulang dari rumah sakit (tergantung yang terjadi lebih dahulu), atau lebih lama apabila pasien memiliki faktor risiko menetap. ${ }^{14}$

Protokol gut decontamination selektif dilakukan pada kandidat transplantasi hati untuk mengurangi kecenderungan infeksi jamur dari sumber intestinal pasca-transplantasi. Nystatin adalah pilihan obat yang paling sering digunakan untuk infeksi tersebut. ${ }^{13}$ Dosis nystatin yang digunakan 200.000 unit -400.000 unit $5 \mathrm{kali} / \mathrm{hari}$ selama $7-14 .{ }^{15}$

Profilaksis infeksi PCP diberikan TrimetoprimSulfametoxazole (TMP-SMX) dengan dosis anak $5 \mathrm{mg} /$ $\mathrm{kg}$ (dosis maksimal $320 \mathrm{mg}$ ) untuk bulan berikutnya setiap Senin/Rabu/Jumat selama 6 bulan sampai 1 tahun. ${ }^{16}$

Obat TMP-SMX merupakan pilihan utama profilaksis PCP pada resipien transplan organ. Profilaksis TMP-SMX ditemukan efektif untuk mencegah PCP khususnya pada pasien HIV-negatif. ${ }^{11}$ Pentamidine aerosol dipertimbangkan sebagai terapi profilaksis alternatif pada resipien yang mengalami mielosupresi atau alergi terhadap TMP-SMX (untuk anak usia 6 tahun atau lebih). Untuk kepentingan rekomendasi ini, mielosupresi didefinisikan sebagai hitung absolut neutrofil atau absolute neutrophil count $\left(\right.$ ANC) $<1000 .^{15}$

Alternatif lain adalah dapsone untuk anak usia lebih dari 1 bulan sampai 6 tahun yang tidak memiliki toleransi terhadap terapi aerosol. Pentamidine intravena diberikan pada resipien yang mengalami mielosupresi atau reaksi samping baik dengan TMP-SMX ataupun dapsone. Terapi profilaksis PCP tertera pada Tabel 1.

Dapsone dan pentamidine aerosol memiliki efikasi yang sama. Namun, dapsone memiliki efek samping 4 kali lipat lebih besar daripada pentamidine aerosol. ${ }^{15}$ Dapsone tidak direkomendasikan pada pasien yang dapat mengalami reaksi hebat, seperti deskuamasi, neutropenia, nefritis interstitial, atau hepatitis ketika diberikan TMP-SMX atau golongan sulfa lainnya. Dapsone juga tidak boleh diberikan pada pasien dengan dengan defisiensi G6PD dan methemoglobin reduktase. Efek samping dapsone yang paling sering terjadi adalah anemia hemolitik dan methemoglobinemia. Gejala tersebut biasanya berkaitan dengan adanya defisiensi enzim G6PD. ${ }^{11}$ Namun, obat dapsone dan pentamidine tidak tersedia di Indonesia.

\section{Diagnosis dan tata laksana infeksi jamur invasif pasca-transplantasi hati}

Definisi infeksi jamur invasif diadopsi dari 2008 European Organization for Research and Treatment of Cancer/Invasive Fungal Infections Cooperative Group (EORTC), yaitu didapatkan minimal satu kultur darah positif berupa Candida sp. atau jamur patogenik lain. Hasil kultur positif dapat mengidentifikasi jenis 
Mulya Rahma Karyanti dkk: Protokol evaluasi infeksi jamur dan parasit pre dan pasca-transplantasi hati anak

Tabel 1. Dosis profilaksis PCP ${ }^{12,17}$

\begin{tabular}{|c|c|c|}
\hline Obat & Dosis anak & Dosis dewasa/ dosis anak maksimum \\
\hline TMP-SMX & $\begin{array}{l}5 \mathrm{mg} / \mathrm{kg} / \text { hari; hanya komponen TMP, } 3 \text { kali } \\
\text { dalam seminggu selama } 6-12 \text { bulan }\end{array}$ & $\begin{array}{c}320 \text { mg TMP/ hari; } 3 \text { kali dalam } \\
\text { seminggu }\end{array}$ \\
\hline Dapsone (untuk usia $\geq 1$ bulan) & $\begin{array}{c}2 \mathrm{mg} / \mathrm{kg}, 1 \mathrm{kali} / \mathrm{hari} \text { atau } 4 \mathrm{mg} / \mathrm{kg} 1 \mathrm{kali} \\
\text { dalam seminggu }\end{array}$ & $\begin{array}{c}100 \mathrm{mg} / \text { hari } \\
200 \mathrm{mg} / \mathrm{minggu}\end{array}$ \\
\hline $\begin{array}{l}\text { Pentamidine aerosol (untuk usia } \\
\geq 6 \text { tahun) }\end{array}$ & $\begin{array}{c}300 \text { mg sekali sebulan via Respirgard II } \\
\text { inhaler }\end{array}$ & $\begin{array}{c}300 \text { mg sekali dalam sebulan via } \\
\text { Respirgard II inhaler }\end{array}$ \\
\hline $\begin{array}{l}\text { Pentamidine intravena (untuk } \\
\text { usia }<6 \text { tahun) }\end{array}$ & $4 \mathrm{mg} / \mathrm{kg} /$ hari 1 kali dalam sebulan & $\begin{array}{l}4 \mathrm{mg} / \mathrm{kg} \text { sekali dalam sebulan (tidak ada } \\
\text { dosis tunggal maksimum) }\end{array}$ \\
\hline
\end{tabular}

Tabel 2. Faktor risiko infeksi jamur pada transplantasi hati ${ }^{12,18}$

\begin{tabular}{lll}
\hline Candida species & Aspergillus species & Cryptococcus species \\
\hline $\begin{array}{l}\text { Operasi transplantasi hati atau choledochojejunostomy } \\
\text { memanjang dan disertai komplikasi }\end{array}$ & $\begin{array}{l}\text { Hepatitis fulminan sebagai indikasi } \\
\text { transplantasi hati }\end{array}$ & Imunosupresi berat \\
Penggunaan antibiotik spektrum luas yang memanjang & $\begin{array}{l}\text { Penggunaan antibiotik spektrum luas } \\
\text { sebelum operasi }\end{array}$ & Penyakit CMV \\
Waktu rawat inap yang memanjang lebih dari 18 hari, & Re-transplantasi \\
khususnya di ICU & & \\
$\begin{array}{l}\text { Dialisis pasca-transplantasi } \\
\text { Transplantasi ulang }\end{array}$ & Imunosupresi berat \\
Kolonisasi Candida & Adanya antigen Aspergillus \\
Penyakit CMV & Penyakit CMV \\
\hline
\end{tabular}

jamur patogen penyebab infeksi. Untuk mendeteksi infeksi Aspergillus dilakukan dengan memeriksa antigen galactomannan dengan cut-off $\geq 0,5$ di mana pemeriksaan tersebut dapat dilakukan di Laboratorium Parasitologi FKUI. Pemeriksaan $\beta$-D-glucan dilakukan untuk identifikasi infeksi kandida dengan cut-off $\geq$ $60 \mathrm{pg} / \mathrm{mL}$, tetapi pemeriksaan ini belum tersedia di Indonesia sampai saat ini. ${ }^{6}$

Faktor risiko untuk terjadinya infeksi kandida adalah organ replacement therapy dengan imunosupresan, faktor operasi (waktu operasi $>11$ jam, operasi kedua dalam interval 5 hari, anastomosis choledo-jejunostomy, produk darah $>40$ Unit selama operasi), faktor mikroba kolonisasi jamur dini (dalam 3 hari) yang terdokumentasi dari nasal, farings, atau rektal, serta gagal hati akut. ${ }^{12}$

Sementara itu, faktor risiko untuk aspergilosis meliputi dialisis, faktor operasi yaitu re-transplantasi, faktor mikroba yakni riwayat kolonisasi sebelumnya dan gagal hati akut ${ }^{12}$ Faktor risiko infeksi jamur pada transplantasi hati tertera pada Tabel 2.

Pemberian antijamur diberikan pada kecurigaan infeksi jamur sistemik. Pilihan antijamur dapat berupa
Mycafungin IV dosis $2 \mathrm{mg} / \mathrm{kg} / \mathrm{hari}, 1 \mathrm{kali}$ sehari, dapat ditingkatkan sampai dosis $4-10 \mathrm{mg} / \mathrm{kgBB} / \mathrm{hari}$, 1 kali sehari. Mycafungin tidak direkomendasikan untuk infeksi saluran kemih yang disebabkan oleh jamur. Pilihan antijamur lainnya adalah Amfoterisin B konvensional 1-1,5 mg/kg/hari, 1 kali sehari dan Fluconazole $12 \mathrm{mg} / \mathrm{kg} / \mathrm{hari}, 1$ kali sehari. Pemberian terapi fluconazole direkomendasikan, tetapi bersifat hepatotoksik sehingga tidak diindikasikan pasca tranplantasi hati. Durasi pemberian antijamur 3-4 minggu atau 2 minggu setalah kultur darah negatif atau 2 minggu setelah perbaikan klinis. Untuk infeksi Aspergillus invasif, pilihan terapinya adalah voriconazole dengan alternatif Amphotericin B. ${ }^{6}$

Pneumocystis pneumonia (PCP) merupakan salah satu infeksi jamur yang dapat ditemukan pada pasien dengan status HIV positif atau dengan immunosupresi. Secara klinis, pasien dengan PCP akan mengalami dyspnea subakut, batuk tidak atau produktif minimal, demam dan malaise. Namun, 7\% dari kasus PCP tidak menampilkan gejala klinis. Pada pasien dengan imunosupresi namun status HIV negatif, gejala klinis muncul secara akut 
dengan sesak napas, demam, menggigil, dan beberapa kasus membutuhkan bantuan vetilasi mekanik. Risiko gagal napas pada grup imunosupresi dapat mencapai mortalitas 40\%. Pemeriksaan X-ray dada umumnya tidak spesifik dan dapat memperlihatkan gambaran yang bervariasi, dimulai dari bilateral dan infiltrat yang simetris. Namun, beberapa gambaran lainnya yang dilaporkan berupa infiltrat lobaris, nodul pulmonal, pneumatoceles, bentuk kista, dan pneumothorax. Pada gambaran yang tidak spesifik, CT-scan dada dapat diindikasikan. Diagnosis baku emas untuk PCP adalah gambaran mikroskopik dari organisme tersebut. ${ }^{19}$

Terapi lini pertama pada PCP yang digunakan sampai saat ini adalah TMP-SMX. Dosis standar yang diberikan untuk anak usia lebih dari 2 bulan adalah $15-20 \mathrm{mg} / \mathrm{kg} /$ hari untuk TMP dan 75-100 mg/kg/hari untuk SMX dengan frekuensi 3-4 kali sehari. Untuk kasus PCP yang berat, pemberian secara intravena lebih disarankan daripada pemberian secara oral, kecuali bila perbaikan klinis telah tercapai. ${ }^{20}$ Durasi pemberian TMP-SMX direkomendasikan selama 21 hari pada pasien dengan HIV positif dikarenakan fungal load yang lebih tinggi pada kelompok ini serta respon terapi yang lebih lambat. Sebaliknya, pada kelompok pasien HIV-negatif, durasi pemberian yang optimal disarankan selama 14 hari namun dapat diperpanjang sampai 21 hari pada infeksi berat atau belum ada perbaikan klinis (III). ${ }^{11,20}$ Selain TMP-SMX, pilihan terapi lainnya untuk tata laksana PCP tertera pada Tabel 3.

\section{Infeksi parasit}

\section{Etiologi infeksi parasit dan dampaknya}

Parasit merupakan organisme penyebab infeksi yang paling sering. Kelompok parasit yang menjadi patogen adalah Toxoplasma, Trypanosoma, Leishmania, Plasmodium, Schistosoma, helminth, dan sebagainya. Infeksi tersebut sering terjadi di daerah tropis dan subtropis. Penularan dapat terjadi baik melalui transfusi darah maupun transplantasi organ. ${ }^{14}$

Tabel 3. Dosis terapi $\mathrm{PCP}^{20}$

\begin{tabular}{|c|c|c|}
\hline Obat & Dosis kuratif & Keterangan \\
\hline TMP-SMX & $\begin{array}{l}\text { TMP: } 15-20 \mathrm{mg} / \mathrm{kg} \\
\text { SMX: } 75-100 \mathrm{mg} / \mathrm{kg} \text {, IV atau PO, } \\
\text { dibagi menjadi } 3-4 \text { kali sehari selama } \\
21 \text { hari }\end{array}$ & $\begin{array}{l}\text { Kontraindikasi: alergi terhadap sulfa. } \\
\text { Efek samping: Sitopenia, reaksi kulit, hepatitis, pankreatitis, } \\
\text { gangguan gastrointestinal, gangguan fungsi ginjal, } \\
\text { hiperkalemia, anafilaksis. } \\
\text { Interaksi dengan siklosporin: peningkatan level kreatinin } \\
\text { dengan kemungkinan penurunan konsentrasi siklosporin } \\
\text { dalam plasma. }\end{array}$ \\
\hline Atovaquone & $750 \mathrm{mg}, 2-3$ kali sehari, PO & $\begin{array}{l}\text { Efek samping: ruam kulit, demam, gangguan } \\
\text { gastrointestinal, hepatitis. }\end{array}$ \\
\hline Pentamidine intravena & $4 \mathrm{mg} / \mathrm{kg} / \mathrm{hari}, 1$ kali sehari, & $\begin{array}{l}\text { Efek samping: pankreatitis, hipo- atau hiperglikemia, } \\
\text { supresi sum-sum tulang, gangguan fungsi ginjal, arritmia, } \\
\text { gangguan keseimbangan elektrolit, hipotensi, hepatitis. } \\
\text { Interaksi dengan obat nefrotoksik lainnya, meningkatkan } \\
\text { toksisitas renal, khususnya siklosporin dan takrolimus. }\end{array}$ \\
\hline Dapsone + TMP & $\begin{array}{l}\text { Dapsone: } 100 \mathrm{mg} \text { per hari, } \mathrm{PO} \\
\text { TMP: } 5 \mathrm{mg} / \mathrm{kg}, 3 \text { kali sehari }\end{array}$ & $\begin{array}{l}\text { Kontraindikasi: defisiensi G6PD. Kemungkinan cross- } \\
\text { reaction dengan alergi sulfa. } \\
\text { Efek samping: methemoglobinemia, anemia, ruam kulit, } \\
\text { gangguan gastrointestinal. }\end{array}$ \\
\hline $\begin{array}{l}\text { Klindamisin + } \\
\text { Primakuin }\end{array}$ & $\begin{array}{l}\text { Klindamisin: } 600 \mathrm{mg} \text {, } 4 \text { kali sehari } \\
\text { IV, atau } 350-400 \mathrm{mg} \text {, } 4 \text { kali sehari } \\
\text { PO } \\
\text { Primakuin: } 15-30 \mathrm{mg} \text { sehari, PO }\end{array}$ & $\begin{array}{l}\text { Kontraindikasi: defisiensi G6PD } \\
\text { Efek samping: ruam kulit, demam, neutropenia, gangguan } \\
\text { gastrointestinal, methemoglobinemia. } \\
\text { Interaksi dengan siklosporin: kemungkinan penurunan } \\
\text { konsentrasi siklosporin dalam plasma. }\end{array}$ \\
\hline
\end{tabular}


Infeksi toksoplasmosis pasca-transplantasi jarang ditemukan, tetapi perlu dipikirkan. Risiko terbesar adalah ketika resepien dengan seronegatif Toxoplasma species menerima donor hati dengan seropositif Toxoplasma species. ${ }^{6}$

Infeksi trypanosomiasis terjadi pada $22-29 \%$ pasien pasca-transplantasi hati dari donor seropositif ke resipien seronegatif. ${ }^{4}$ Selain itu, infeksi leishmaniasis juga sering terjadi pada pasien pasca-transplantasi hati.

Infeksi oleh plasmodium juga ditemukan pada pasien tranplantasi hati yang mendapat organ dari donor yang berasal dari daerah endemik. ${ }^{4}$ Pasien dari area endemik atau yang telah melakukan perjalanan ke area endemik Strongyloidiasis dalam jangka waktu yang lama berisiko terjadi strongyloidiasis diseminata setelah transplantasi. ${ }^{21}$

\section{Uji tapis pada infeksi parasit}

Toksoplasmosis sangat jarang ditransmisikan pada resipien transplantasi hati. Uji tapis donor untuk Toxoplasma species bukanlah hal rutin yang dilakukan pada donor hati. ${ }^{6,22}$ Namun, tes serologi untuk toxoplasmosis pada donor rutin dilakukan di 11 negara Eropa sebagai salah satu evaluasi pretransplan organ. ${ }^{23}$

Trypanosomiasis sering terjadi di Amerika. Uji tapis trypanosomiasis dilakukan dengan pemeriksaan serologi: enzyme immunoassay, indirect hemagglutination dan indirect immunofluorescence atau apus darah tipis dan pewarnaan giemsa untuk infeksi akut. Uji tapis untuk Plasmodium dengan pemeriksaan asam nukleat lebih sensitif dibandingkan dengan pemeriksaan apus darah tebal maupun tipis. ${ }^{4}$

Uji tapis untuk strongyloidiasis dilakukan dengan pemeriksaan telur dan parasit, beberapa ahli menganjurkan uji tapis dengan pemeriksaan serologi karena lebih sensitif daripada pemeriksaan tinja (III). Untuk pasien seropositif terhadap Strongyloides, diberikan ivermectin atau thiabendazole jangka pendek diindikasikan sebelum transplantasi. Pilihan obat yang biasanya digunakan adalah ivermectin $0,2 \mathrm{mg} / \mathrm{kg} / \mathrm{hari}$ selama 2 hari; beberapa klinisi merekomendasikan pengulangan dosis dan waktu yang sama untuk satu minggu kemudian. ${ }^{6}$

\section{Profilaksis / antiparasit (toxoplasma) sebelum transplantasi hati}

Tidak ada profilaksis sebab angka kejadian tokso- plasmosis setelah transplantasi organ non-kardiak, termasuk hati sangat rendah. Namun, profilaksis diindikasikan pada transplantasi hati. Profilaksis pada transplantasi hati menggunakan TMP-SMX. ${ }^{24}$

Rekomendasi untuk profilaksis antiparasit, inisiasi profilaksis dipertimbangkan dalam sebulan pasca transplantasi dan dilanjutkan minimal selama 6 bulan. Sebagai tambahan terhadap periode insiasi profilaksis di atas, re-inisiasi dimungkinkan selama periode rejeksi atau terapi graft versus host disease karena peningkatan imunosupresan. ${ }^{22}$

\section{Diagnosis dan tata laksana infeksi parasit pasca- transplantasi hati}

Diagnosis toxoplasmosis pada pasien pasca-tranplantasi hati dilakukan dengan CT-scan dan MRI yang menunjukkan gambaran ring-enhancing lesions pada otak dikelilingi edema atau lesi difus yang menunjukkan ensefalitis dan gambaran pada paru berupa konsolidasi pada alveolar dengan pneumonitis interstitial yang menandakan adanya toxoplasmosis pulmonal. Selain itu infeksi toxoplasmosis juga dapat dilihat dari pewarnaan giemsa melalui spesimen apus darah, cerobrospinal fluid, bronchoalveolar lavage, dan spesimen lainnya. Pemeriksaan serologi IgM dan IgG antibodi juga dilakukan untuk melihat adanya infeksi toxoplasma. ${ }^{4}$

Terapi pilihan yang digunakan adalah Pyrimethamine $2 \mathrm{mg} / \mathrm{kg} / \mathrm{hari}$ per oral ditambah sulfadiazine $100-200 \mathrm{mg} / \mathrm{kg} / \mathrm{hari}$ setiap 6 jam per oral ditambah leucovorin $10-25 \mathrm{mg} / \mathrm{hari}$ per oral selama 6 minggu. Selain itu, terapi alternatif yang dapat diberikan Pyrimethamine $2 \mathrm{mg} / \mathrm{kg} / \mathrm{h}$ ari per oral ditambah Clindamycin 20-40 mg/kg/hari per oral setiap 6 jam selama 6 minggu. ${ }^{4}$

\section{Penutup}

Evaluasi infeksi jamur dan parasit baik pre- maupun pasca-transplan hati merupakan bagian terpenting dalam proses transplantasi. Uji tapis pasien dengan risiko infeksi aktif dan laten dapat menentukan apakah resipien dapat menjadi kandidat tranplantasi hati saat itu dan berpengaruh pada pilihan profilaksis yang diberikan pada resipien pre- maupun pascatransplantasi hati untuk menurunkan morbiditas dan mortalitas. 
Mulya Rahma Karyanti dkk: Protokol evaluasi infeksi jamur dan parasit pre dan pasca-transplantasi hati anak

\section{Daftar pustaka}

1. Zicker M, Colombo AL, Ferraz-Neto B, Camargo LF. Epidemiology of fungal infections in liver transplant recipients: a six-year study of a large Brazilian liver transplantation centre. Mem Inst Oswaldo Cruz 2011 [cited: 2018 June 29];106. Didapat dari: http://www.scielo.br/scielo. php?script=sci_arttextópid=S0074-02762011000300014.

2. Silviera FP, Husain S. Fungal infections in solid organ transplantation. Medical Mycology 2007;45:305-20.

3. Rahman HA. Faktor risiko kejadian kandidemia pada anak di RS Dr. Cipto Mangunkusumo tahun 2012-2017. Program S2 Anak [Tesis]. Jakarta: Universitas Indonesia.

4. Barsoum RS. Parasitic infection in transplant recipients. Nat Clin Pract Nephrol 2006;2:490-503.

5. Green M, Michaels MG. Infections in pediatric solid organ transplant recipients. JPIDS 2012;2:144-51.

6. Schwartz BS, Mawhorter, the AST infectious disease community of practice. Parasitic infection in solid organ transplantation. Am J Transplant 2013;13:280-303.

7. Tan BH, Chakrabarti, Patel AK, Watcharananan SP, Liu Z, Chindamporn A, dkk. Incidence and species distribution of candidemia in Asia: A laboratory-based surveillance study. Clin Microbiol Infect 2015;21:946-53.

8. Ohkubo T, Sugawara Y, Takayama T, Kokudo N, Makuuchi $\mathrm{M}$. The risk factors of fungal infection in living-donor liver transplantations. J Hepatobiliary Sci 2012;19:382-88.

9. Ricciardi A, Ndao M. Diagnosis of parasitic infection: what's going on? J Biomol Screen 2015;20:6-21.

10. Silvieira FP, Kusne S. The AST infectious disease community of practice. Candida infection in solid organ transplatation. Am J Transplant 2013;13:220-27.

11. Martin SI, Fishman JA. AST infectious disease community of practice. Pneumocystis pneumonia in solid organ transplantation. Am J Transplant 2013;13:272-79.

12. Fagiuoli S, Colli A, Bruno R, Craxì A, Gaeta GB, Grossi $\mathrm{P}$, dkk. Management of infections pre- and post-liver transplantation: report of a AISF consensus conference. J
Hepatol 2014;60:1075-89.

13. Peter G, John R, Jack S, Scott F, William D, Thomas W, John E. Guidelines for treatment of candidiasis. Clin Infect Dis 2004;38:161-89.

14. Fischer SA, Avery RK. Screening of donor and recipient prior to solid organ transplantation. Am J Transplant 2009;9:7-18.

15. Evans JD, Morris PJ, Knight SR. Antifungal prophylaxis in liver transplantation: a systematic review and network metaanalysis. Am J Transplant 2014;14:2766-76.

16. Berquist W, Cox K, Dyner L, Enns G, Esquivel C, Hurwitz $\mathrm{M}$, dkk. The pediatric transplant protocols and guide to management of transplant patients. USA: Stanford Children's Health-Lucile Packard Children's Hospital Stanford; 2014.

17. Krishnan KR, Bhattacharya R, Pereira A, Otto AK, Carithers RL, Reyes JD, dkk. The HALOS-ND model: A step in the journey of predicting hospital length of stay after liver transplantation. Clin Transplant 2013:27:809-22.

18. Cincinnati Children's Hospital Medical Center. Evidence-Based Care Guideline: Pneumocystis Carinii Pneumonia Prophylaxis following Solid Organ Transplant 2007. 2015 [cited: 2016 January 26]. Didapat dari: http://www.cincinnatichildrens.org/ WorkArea/DownloadAsset.aspx?id=127428.

19. Carmona EM, Limer AH. Update on the diagnosis and treatment of pneumocystis penumonia. Ther Adv Respir Dis 2011;5:41-59.

20. Xavier I, Bouar ML, Kamar N, Berry A. Pneumocystis pneumonia in solid-organ transplant recipients. J Fungi 2015;1:293-331.

21. Avery RK. Recipient screening prior to solid-organ transplantation. Clin Infect Dis 2002;35:1513-9.

22. Khurana S, Batra N. Toxoplasmosis in organ transplant recipients: Evaluation, implication, and prevention. Trop Parasitol 2016;6:123-8.

23. Len O, Garzoni C, Lumbreras C, Molina I, Meije Y, Pahissa A, dkk. Recommendations for screening of donor and recipient prior to solid organ transplantation and to minimize transmission of donor-derived infections. Clin Microbiol Infect 2014;20:10-8. 